\title{
Juridical Review Process Completion Code Violation of Notary
}

\author{
Eli Tri Kursiswanti ${ }^{1}$, Yeremias Tony Putrawan ${ }^{2}$ and Gunarto ${ }^{3}$
}

Abstract. The purpose of this study were 1) To explain the juridical review process completion code violation of notary, 2) To explain the process of resolving the obstacles and solutions notary code violations.

The methods in this research is juridical-empirical approach. Judicial approach used to analyze a wide range of laws and regulations related to the implementation of sanctions for violations of the code of conduct notary, In this study, then this kind of research will be a descriptive analysis that describes, depicts or expressessanctions for violations of the code of notary conduct.

Based on the results of this study concluded that 1) Notary is a public official who has the authority to make an authentic deed as an evidence that has the strongest evidence in civil law. Notary profession in practice arranged in a special instrument that Notary Code. Not with standing remains a violation of Notary Code. These violations need to be enforced to ensure legal certainty for citizens. 2) The obstacle is the lack of awareness of the Notary to abide by a code of ethics, and supplies obtained Notary is not enough for his education, and still overlapping provisions of the code of conduct between the supervision of the Honorary Board and the Supervisory Council of Notaries. In an effort to prevent and reduce the occurrence of violations of the Code notary in Depok then the WCA Board and the Supervisory Council of Notaries to guidance, supervision, guidance and counseling. Included in providing strict sanctions as part of the coaching. Doing awards (reward) and punishment to the Notary in implementing the Notary Code provisions.

Keywords: Judicial Review; Settlement; Breach; The Code; Notary.

\section{Introduction}

Notary institution is one of the social institutions that exist in Indonesia. This institution arising from the needs of society requires an evidence of the relationship existing civil law and will occur between them. Given the increasing needs of the community and will Notary services Notary then formed specifically to serve the public in the field of civil, especially in making authentic act as it turns out in article 1868 of the Civil Code, namely: "Authentic deed is a deed in the form prescribed by law, be made by or before public officials in power to it at the place where the deed made."4

Indonesia as a state of law, as contained in Article 1 (3) of the Constitution of the Republic of Indonesia, 1945. Then all aspects of life in society to be unfounded and should not deviate from the norms of law in Indonesia. Related to this the notary institution in civil relationships involving an authentic deed must be made by a Notary Public.

Although the Notary as a public official authorized by the State to create the authentic act does not rule out the occurrence of violations committed by the Notary itself, and

1 Master of Notary Law Student, Sultan Agung Islamic University Semarang, e-mail: eli.bayusinta@gmail.com

2 Students of Master of Law, Faculty Of Law, Universitas Islam Sultan Agung email yeremias.2006.71@gmail.com

${ }^{3}$ Lecturer in Faculty of Law, Sultan Agung Islamic University

${ }^{4}$ The draft Civil Code [Burgerlijk Wetboek], translated by Subekti and R. Tjitrosudibio, (Jakarta:

Pradnya Paramita, 1996), Ps. 1868 
therefore drafted a code of conduct established by the Notary Public Notary Association of Indonesia. The objective of the code of conduct is to be a Notary Public Notary profession can be run by professionals with motivation and orientation on intellectual skills as well as arguing rationally and critically and uphold the moral values. But when today many notaries who ignore these things, so the level of a violation of the code of ethics Notary increasing. Code violations include violations of the norms, both the norms of religion, morality, decency and rule of law.

The code of ethics is part of the positive law, made in writing, but do not have harsh sanctions. This enforceability solely on the basis of moral consciousness, unlike the legislation coercive. Reason waiver of this code of conduct is influenced by economic factors, social, political, cultural, religious, technological, and so on. All these elements are interconnected, mutually binding and mutually affect one another.

In a Notary Public Ethics code Article No 5, which among other things about the personality of a Notary, the Notary in their duties, notary with clients, notary with peers and the last of supervision. Notary as a public official in performing his duties imbued Pancasila, conscious and obey the law as well as a good personality and uphold the dignity and honor of notary (Article 1 Notary Code).

Furthermore, according to the provisions of Article 2 Notary Code explains that: "Notary in carrying out his obligations aware of his own work, honestly and impartially, with a full sense of responsibility, do not hold a branch office, and not to use intermediaries as well as the use of mass media promotional nature. Providing services to people who need his service with the best gives legal counseling as well as providing services to the poor for free ".

A Notary in carrying out his position must be professional with based on noble personality to always implement the law at the same time uphold the Code of Ethics by profession ie Notary Code. A Notary is expected to act honestly, thoroughly, independently, impartially, and safeguard the interests of those involved in the legal interest, as stipulated in Article 16, Paragraph 1 a of Law Number 30 of 2004 concerning Notary. Notaries must be able to follow the development of the law so as to provide services to the community, in helping to address and meet the needs of evolving law may provide a way out is not justified by law. Therefore, a notary in performing their duties must comply and be bound by the existing regulations, namely Notary Law, the draft Civil Code, Notary Code and other Regulations. ${ }^{5}$

Position carried of Notary is a position of trust that is mandated by law and society, for which a Notary is responsible for carrying out the trust given to him by always uphold the ethics of law and the dignity and nobility of his position, because if it is passed by a Notary Public, it would be dangerous for the general public it serves. In his do the job, Notary must comply with all the moral code live and thrive in society. Aside from the responsibilities of the ethics of the profession, their integrity and morals are essential requirements that must be owned by a Notary Public. Morals are morals, manners associated with poorly received good overview of the actions, attitudes, and liabilities. ${ }^{6}$ Notary as a profession is the main basis of trust and notary bear a heavy mandate for the trust given by the people to him. Value is more than a profession is as far as whether a professional is able to resist the temptation to distort the confidence entrusted to them, but the temptation to misappropriate trust so great foundation in

\footnotetext{
${ }^{5}$ Putri A.R., Perlindungan Hukum Terhadap Notaris Indikator Tugas-Tugas Jabatan Notaris yang Berimplikasi Perbuatan Pidana,PT. Sofmedia 2011, p. 5.

${ }^{6}$ Anke Dwi Saputro (ed), Jati Diri Notaris Indonesia dulu, sekarang dan masa mendatang (Pengurus Pusat Ikatan Notaris Indonesia, 2008), p.193.
} 
the form of morality is an absolute to be built Notary as a group on board, has a large contribution to the wider community in build morality. ${ }^{7}$

Based on the background of the problems that have been raised the problem in this research is formulated as follows: How to juridical review process completion code violation of notary? How barrier and settlement process solutions notary code violations?

\section{Research methods}

This study is a juridical-empirical approach. Judicial approach used to analyze a wide range of laws and regulations related to the implementationsanctions for violations of the code of conduct notary, while empirical approach was used to analyze the law is seen as society patterned behavior in public life are always interacting and relating in the community aspects. ${ }^{8}$

In this study, then this kind of research will be a descriptive analysis that describes, depicts or expresses sanctions for violations of the code of conduct notary, It is then discussed or analyzed by science and theories or opinionsresearchers themselves, and finally concludes.

\section{Discussion}

\subsection{Juridical Review Process Completion Code Violation Of Notary}

Unprofessional Notary often ignored the rules of the Code of Conduct law profession because some of the most fundamental reason either as individual members of society as well as labor relations in professional organizations in addition to the consumerist human nature and value of remuneration which is disproportionate to the services rendered, on the basis these factors, it can be inventoried fundamental reasons why professionals tend to ignore and even melannggar code of conduct, among others: ${ }^{9}$

- Influence of Kinship properties;

- Effect of Position;

- Influence of Consumerism; and.

- Due to Weak Faith.

A violation of the code of conduct does not necessarily directly sanctioned. Should an inspection for the violation. In accordance with the Notary Code, the process of resolving an ethical violation as follows:

- Supervision (Article 7)

- At the district / city level by the Regional Board and the Regional Ethics Board.

- At the provincial level by the Regional Board and the Regional Ethics Board.

- At the national level by the Central Board and the Honorary Board of the Center.

- Facts Alleged Violation (Article 8)

Honor Council fact-finding on the alleged violations of the Code by members of the association on its own initiative or on a complaint in writing from members of the association.

- Inspection and imposition of sanctions (Article 9)

\footnotetext{
${ }^{7}$ Abdul Ghofur Anshori, Lembaga Kenotariatan Indonesia (UII Press, Yogjakarta, 2009), p. 1

${ }^{8}$ Bambang Sunggono, Metodologi Penelitian Hukum, PT Raja Grafindo Persada, Jakarta, 2003, p. 43.

${ }^{9}$ Muhammad Abdulkadir, Etika Profesi Hukum,Jakarta:CV Citra Aditya Bakti,2001, p.83-84.
} 
- Honorary Board after finding the facts violations of the code of conduct, at least 14 days should call a member of the allegedly infringing. If not present called back 14 days, until the call is three.

- If until the third call was not present Honorary Council will remain in session and the decision making process in the form of sanctions.

- If they are not convicted of violations, then the member is restored to its name with the Decree of the Honorary Board of the check.

- Inspection and Imposition of Sanctions On Appellate (10)

- Proposed maximum of 30 days after receipt of the Decree sanctioning of the Honorary Board.

- Submitted in writing to the Council of Honor

The violations committed by the Notary sanctioned if found guilty of the offense. Penalties for violations stipulated in Article 6 of the Notary Code and Article 85 UUJN, namely:

- Reprimand

- Warning

- Suspension of membership associations

- Dismissal discharged from association membership

- Dishonorable discharge from the membership of the association.

The sanctions which have been mentioned above, violation of code violations deed Notary outside the office which is forbidden for Notary as stipulated in Article 17 paragraph (1), sanctions adapted to Article 9 paragraph (1) pint (d), namely: "Notary suspended from office for: d. Did violation of the obligations and prohibitions Notary office and code of ethics. "

So the sanctions that can be imposed by the Council of Honor of the Notary who proved to have violated the code of conduct in the form of a notary deed outside the office is layoffs.

\subsection{Barriers and Solutions Process on Notary Code Violations}

In principle, the Notary Code is a moral code that must be obeyed by all Notaries in Indonesia. Because ethics is closely related to the moral then every Notary in running position must own and live the values of the Notary Code. Notary good personality, honest, trustworthy, independent and professionally bound to implement the spirit of Notary Code by making it as guidance and reference in carrying out his profession as a notary. This attitude should be applied and internalized by Notary continuously either because someone is watching or not. Supervision and oversight function of the notary is aimed at bringing order, rule of law and protection of the law on justice and truth, as expected by the public notary services. ${ }^{10}$

The difficulty of implementation of the code of professional conduct by members of the profession is very unfortunate, because the profession is basically run by professionals who have the ability, knowledge, and capacity who are competent in their field. As for some of the weaknesses of professional code of ethics, among others:

- Idealism is contained in the code of ethics is not inline with the facts that occurred around the professionals, so more far hope from reality. It is quite intriguing professionals to turn to the reality and idealism ignore professional ethics. The code of ethics is nothing more than a display framed article.

${ }^{10}$ Binsar Tobing, "Peran MPD Sangat Strategis", Majalah Renvoi Nomor: 3.87 Agustus 2010, p. 51. 
- Professional code of ethics is a set of moral norms that are not equipped with tough sanctions for enforceability solely on the basis of professional awareness. Apparently these shortcomings provide an opportunity for professionals weak in faith to do deviate from the code of conduct of his profession.

Some of the obstacles encountered in the process of settlement notary code violations:

- Some areas are difficult for the formation of the Regional Supervisory Council. These circumstances make it difficult to provide guidance and supervision of the implementation of the notary office as a routine inspection by the Supervisory Council.

- Technical equipment such as the existence of the secretariat of the Supervisory Council, including human resources, office supplies, computers, archives etc. place. With the lack of adequate technical equipment cause can not do the maximum supervision of the track record notaries including whether it has not posted notary according UUJN obligations, notes about the mistakes that have been made notary and giving sanctions.

- Not to be held at least once a year periodic examination by the Investigation Team.

- The procedure for supervision that is not "uniform" by the Investigation Team of the notaries who have not been uniform, sometimes creating confusion among notaries despite some decrees of M-39-PW.07.10 2004.

- The procedure for summoning and examination of a notary public notary is not the same by the Board of Trustees in their reports from the public, or at the request of investigators, prosecutors or judges.

- The difficulty for the nomination of the members of the Supervisory Council of the government and / or experts / academics in some particular area despite the provisions of Article 67 paragraph (4) UUJN.

- The funds available are inadequate so it does not support the implementation of the optimal guidance and supervision by the Supervisory Council of the notary.

Solution settlement process notary code violations are:

- Consciously with the support of a strong willingness of the notary each to enforce the Notary Code.

- Notary Code retain autonomy through an independent notary organization and recognized and respected by the community.

- Notaries science curriculum, processes, and methods of education that includes efforts to systematically cultivate an ethical stance in accordance with the notary profession.

\section{Closing}

\subsection{Conclusion}

- Notary is a public official who has the authority to make an authentic deed as an evidence that has the strongest evidence in civil law. Notary profession in practice arranged in a special instrument that Notary Code. Not with standing remains a violation of Notary Code. These violations need to be enforced to ensure legal certainty for citizens.

- The obstacle is the lack of awareness of the Notary to abide by a code of ethics, and supplies obtained Notary is not enough for his education, and still overlapping provisions of the code of conduct between the supervision of the Honorary Board and the Supervisory Council of Notaries. In an effort to prevent and reduce the occurrence of violations of the Code notary in Depok then the Honorary Board and the Supervisory Council of Notaries to guidance, supervision, guidance and 
counseling. Included in providing strict sanctions as part of the coaching. Doing awards (reward) and punishment to the Notary in implementing the Notary Code provisions.

\subsection{Suggestion}

- Legal instrument or a regulation should be made a change to remain relevant to the times agara there. This is done so that there is no error juridical in Indonesia.

- Improve infrastructure and facilities to support operational performance. To be able to perform preventive and curative efforts in terms of preventing violations Notary Code, it would require the Notary Supervisory Council and the Council of Honor solid, tough and brave to enforce norms and moral values contained in the Notary Code consistently and indiscriminately.

\section{References}

[1] Abdul Ghofur Anshori, 2009, Lembaga Kenotariatan Indonesia, UII Press, Yogjakarta

[2] Anke Dwi Saputro (ed), 2008, Jati Diri Notaris Indonesia dulu, sekarang dan masa mendatang (Pengurus Pusat Ikatan Notaris Indonesia)

[3] Bambang Sunggono, 2003, Metodologi Penelitian Hukum, PT Raja Grafindo Persada, Jakarta

[4] Binsar Tobing, "Peran MPD Sangat Strategis", Majalah Renvoi Nomor: 3.87 Agustus 2010

[5] Subekti dan R. Tjitrosudibio, 1996, The draft Civil Code [Burgerlijk Wetboek], (translated) Jakarta:Pradnya Paramita

[6] Muhammad Abdulkadir,2001, Etika Profesi Hukum, Jakarta:CV Citra Aditya Bakti

[7] Putri A.R., 2011, Perlindungan Hukum Terhadap Notaris Indikator Tugas-Tugas Jabatan Notaris yang Berimplikasi Perbuatan Pidana, PT. Sofmedia 